\title{
PENGEMBANGAN PARIWISATA KOTA BATU YANG BERDAYA SAING
}

\author{
Oleh \\ Edriana Pangestuti \\ Universitas Brawijaya \\ Email: edriana_fia@ub.ac.id
}

\begin{abstract}
East Java, especially Batu City has the potential to be developed into a tourist city with many natural and cultural tourist attractions. The attraction can be used to attract tourists to visit East Java and improve the competitiveness of tourism in Batu. Understanding of the factors that influence the improvement of competitiveness and their implications for tourism development is the basis of this research. This study used a qualitative descriptive approach with the types of primary and secondary data obtained from observation and interviews and direct observation. The results explained that Batu City has alot of tourism destination and the government focused on building it. While the facilities and infrastructure were still lack of budged. However, the conducive and the secure condition of Batu City supported by mass media and technology greatly attract tourist come to Batu City
\end{abstract}

Keywords: Development Strategy, SWOT \& Tourism.

\section{PENDAHUALUAN}

Pentingnya pengembangan pariwisata membuat Indonesia menggalakkan sektor ini untuk menggerakkan industri industri kecil dan meraih peluang keuntungan dari sektor pariwisata dalam menghimpun kekuatan dan strategi dalam mencapai pertumbuhan ekonomi yang baik. pengembangan pariwisata adalah suatu proses yang berkesinambungan untuk melakukan matching dan adjustment yang terus menerus antara sisi supply dan demand kepariwisataan yang tersedia untuk mencapai misi yang telah ditentukan (Novrani, 2007). Strategi pengembangan menurut Sunaryo (2013) pada prinsipnya berkaitan dengan persoalan: Kebijakan pelaksanaan, penentuan tujuan yang hendak dicapai, dan penentuan cara-cara atau metode penggunaan sarana-prasarana. sekarang ini, bidang pariwisata merupakan salah satu kegiatan yang mempunyai peranan yang sangat strategis dalam menunjang pembangunan perekonomian nasional. Sektor ini dicanangkan selain sebagai salah satu sumber penghasil devisa yang cukup andal, juga merupakan sektor yang mampu menyerap tenaga kerja dan mendorong perkembangan investasi. Untuk mengembangkan sektor ini pemerintah berusaha keras membuat rencana dan berbagai kebijakan yang mendukung kearah kemajuan sektor ini. Salah satu kebijakan tersebut adalah menggali, menginventarisir dan mengembangkan obyek-obyek wisata yang ada sebagai daya tarik utama bagi wisatawan.

Jawa Timur merupakan provinsi paling timur pulau Jawa yang memiliki potensi objek wisata terbanyak di Jawa, sekitar 628 objek wisata yang tersebar di seluruh kota di Jawa Timur. Setiap kota memiliki setidaknya lebih dari 10 objek wisata di dalamnya. Batu merupakan salah satu kota yang memiliki berbagai macam potensi. Secara geografis, Batu diuntungkan dengan adanya pegunungan yang mengelilinginya sehingga kota Batu menjadi satu - satunya kota di Jawa Timur yang memiliki gunung terbanyak. Kondisi alam tersebut menjadikan kota Batu memiliki panorama yang indah, udara yang sejuk dan berpotensi menarik semakin banyak jumlah wisatawan. Pemandangan yang indah, hawa yang sejuk, sumber daya hutan dan air yang melimpah berpotensi untuk diberdayakan semaksimal mungkin secara bijaksana menjadi sebuah wisata alam yang menarik. Selain itu, kota Batu juga memiliki keunggulan di sektor pertaniannya. Komoditi pertaniannya meliputi tanaman pangan, tanaman holtikultura, tanaman bunga dan tanaman toga (Batu Milestone, 2012).

Vol.14 No.3 Oktober 2019 
Tiga aspek keunggulan yang telah disebutkan diatas merupakan beberapa hal yang tidak dimiliki atau hanya dimiliki oleh sebagian kecil kota-kota lain terutama di Jawa Timur. Oleh karena itu ketiga hal tersebut dapat disebut sebagai keunggulan kompetitif bagi Kota Batu. Keunggulan kompetitif (Destination competitiveness) dapat ditingkatkan dengan kerjasama yang tepat antara destination resources dan atraksi, perencanaan strategis yang tepat dan peningkatan upaya strategi daya saing (Crouch dan Ritchie 1999, Gomezelj dan Mihalic 2008, Yoon et al., 2001). Crouch dan Ritchie (1999) menyatakan bahwa untuk membuat destinasi yang kompetitif, kualitas pelayanan yang baik dan pengalaman yang memuaskan sangat dibutuhkan untuk menarik wisatawan. Oleh karena itu untuk mencapai daya saing wisata, sebuah kolaborasi yang baik antara strategi pemasaran dan manajemen harus dikembangkan (Cracolici et al., 2008, AlMasroori, 2006a). Chen et al., (2011a) menyatakan bahwa destination competitiveness dapat ditingkatkan dengan meningkatkan atraksi destinasi yang tepat dan kinerja pelayanan untuk memuaskan pelanggan, mendorong mereka untuk tidak hanya meninjau kembali tujuan tetapi juga merekomendasikan hal ini kepada orang lain. Semakin positif image suatu destinasi, semakin besar manfaat yang akan diperoleh destinasi tersebut.

Image/ citra suatu destinasi adalah faktor yang paling penting karena mempengaruhi tingkat kepuasan serta perilaku setelahnya termasuk didalamnya word-of-mouth dan kunjungan berikutnya. Dengan demikian, pengalaman positif wisatawan akan pelayanan, produk dan sumber daya lain yang disediakan oleh destinasi wisata adalah sangat penting (Yuksel, 2007). Rekomendasi dari wisatawan yang telah berkunjung ke destinasi dapat dijadikan sebagai sumber informasi yang paling handal untuk calon wisatawan berikutnya (Chi dan $\mathrm{Qu}$, 2008). Oleh karena itu industri pariwisata harus meningkatkan image destinasi mereka untuk lebih menarik minat wisatawan mengunjungi destinasi. Image atau citra yang positif mengenai objek wisata heritage secara khusus diyakini menghasilkan hal yang positif untuk destination competitiveness (Timotius dan Nyaupane, 2009a). Keunikan destinasi juga dapat menarik wisatawan. Oleh karena itu, dengan memahami image destinasi, kontribusi positif terhadap kepuasan wisata dan daya saing destinasi akan diperoleh (Dwyer dan Kim, 2003). Dengan demikian manajer wisata harus menggali keunggulan-keunggulan kompetitif suatu destinasi dan menganalisis daya saing destinasi. Oleh karna itu tujuan dalam penelitian ini adalah untuk 1. mengetahui dan mendiskripsikan upaya pengembangan pariwisata Kota Batu; 2. mengetahui dan mendiskripsikan hambatan atau kendala yang dihadapi dalam upaya pengembangan pariwisata Kota Batu dan 3. mengetahui dan merumuskan strategi pengembangan pariwisata yang tepat untuk diterapkan di Kota Batu.

\section{LANDASAN TEORI Konsep Strategi}

Definisi strategi menurut Jhonson dan Kevan dalam (Hutabarat dan Husein, 2008) adalah arah dan cakupan jangka Panjang suatu organisasi untuk mendapatkan keuntungan melalui konfigurasi sumberdaya lingkungan yang berubah untuk mencapai kebutuhan pasar dan memenuhi harapan berbagai pihak. Hal tersebut serupa dengan apa yang disampaikan oleh Chalder dalam Salusu (1996) bahwa strategi adalah penetapan jangka Panjang serta penerapan serangkaian tindakan dan alokasi daya yang penting utuk mencapai tujuan tersebut. Sehingga dapat disimpulkan bahwa strategi adalah sekumpulan pilihan kritis untuk perencanaan dan penerapan serangkaian rencana tindakan dan alokasi sumber daya yang penting dalam mencapai tujuan dasar dan sasaran, dengan memperhatikan keunggulan kompetitif komperatif dan sinergis yang ideal berkelanjutan sebagai arah dan perspektif jangka Panjang keseluruhan yang ideal dari individu atau organisasi.

\section{Manajemen Strategis}

http://ejurnal.binawakya.or.id/index.php/MBI 
Manajemen strategis dapat didefinisikan sebagai seni dan pengetahuan dalam merumuskan, mengimplementasikan serta mengevaluasi keputusan-keputusan lintas fungsional yang memampukan sebuah organisasi mencapai tujuan atau serangkaian keputusan dan tindakan mendasar yang dibuat oleh manajemen puncak dan diimplementasikan oleh seluruh jajaran organisasi tersebut. Menurut Azhar (2003) "strategic management is the systematic and continuous process of selecting, implementing and evaluating strategic choices. These decisions must be congruent with the organization's mission, objective and internal and external capabilities, for they will set the tone for the entire organization". Kajian manajemen strategi menjadi kebutuhan yang sangat penting. Pengabaian terhadap manajemen strategis dapat menyebabkan kegagalan dalam beradaptasi terhadap dinamika lingkungan dan menciptakan perubahan manajemen strategis yang semakin berkembang cepat.

\section{METODE PENELITIAN}

Penelitian ini menggunakan metode qualitative. Qualitative research methods telah banyak dipergunakan khususnya untuk social science field (Creswell, 2009b). Penelitian ini dilakukan pada destinasi wisata kota Batu- Jawa Timur, dengan pertimbangan bahwa kota Batu merupakan kota wisata unggulan di Jatim. Metode pengumpulan datan dengan menggunakan Snowball sampling method dengan Tehnik analisis yang akan digunakan adalah SWOT yaitu untuk mengetahui kekuatan (Strenghts), kelemahan (Weakness), peluang (Opportunities), dan ancaman (Threats) dari lingkungan eksternal perusahaan (Jogiyanto,2005).

\section{HASIL DAN PEMBAHASAN}

Berdasarkan analisis SWOT menunjukkan hasil sebagai berikut:

\section{Kekuatan (Strength)}

Kota Batu diuntungkan dengan kondisi geografis yang dikelilingi oleh pegunungan, sehingga pertanian, perkebunan dan tempat http://ejurnal.binawakya.or.id/index.php/MBI wisata alam yang dapat dijadikan potensi unggulan. Potensi tersebut membawa dampak pada pertumbuhan multiplier effect pariwisata lainnya misalnya ketersediaan sarana dan prasarana yang mendukung kegiatan wisata di Kota Batu.

\section{Kelemahan (weakness)}

Kualitas SDM yang berpengalaman dalam bidang pariwisata masih sangat kurang. Selain itu kurangnya pemahaman dan keterlibatan masyarakat sekitar terhadap permintaan pasar (pariwisata). Misalnya cindera mata khas Kota Batu yang tidak bervariatif.

\section{Peluang (opportunity)}

Dukungan pemerintah daerah yang sangat tinggi dalam mewujudkan visi Kota Batu yang berdaya saing. Potensi wisata alam dan budaya yang dimiliki pun menjadi daya tarik tidak hanya bagi wisatawan tapi bagi investor yang ingin mengembangkan potensi yang ada di Kota Batu.

\section{Ancaman}

Kondisi Ekonomi Asia yang mengharuskan setiap destinasi untuk berstandar internasional dan tidak didukung oleh kualitas dan kuantitas sumber daya manus yang memadahi. Selain itu kondisi geografis Kota Batu sangat memungkinkan untuk terjadinya bencana alam misalnya tanah longsor dll.

Berikut adalah matrik SWOT

\begin{tabular}{|c|c|c|}
\hline Internal & Kekuatan (S) & Kelemahan (W) \\
\hline & $\begin{array}{l}\text { Potensi wisata } \\
\text { yang sangat } \\
\text { banyak } \\
\text { Dukungan } \\
\text { pemerintah } \\
\text { daerah }\end{array}$ & $\begin{array}{l}\text { Kualitas SDM yang } \\
\text { belum maksimal } \\
\text { Keterlibatan } \\
\text { masyarakat dalam } \\
\text { pengembangan } \\
\text { pariwisata yang } \\
\text { masih kurang }\end{array}$ \\
\hline Peluang $(\mathrm{O})$ & Strategi SO & Strategi WO \\
\hline $\begin{array}{l}\text { Banyak investor } \\
\text { yang ingin } \\
\text { menginvestasikan } \\
\text { modalnya untuk } \\
\text { pengembangan } \\
\text { wisata Kota Batu } \\
\text { Situasi keamanan } \\
\text { yang kondusif } \\
\text { Perkembangan } \\
\text { media social yang } \\
\text { sangat pesat }\end{array}$ & $\begin{array}{l}\text { Menerapkan } \\
\text { peraturan } \\
\text { perundang- } \\
\text { undangan untuk } \\
\text { investor } \\
\text { Memotivasi } \\
\text { personil untuk } \\
\text { berkomitmen } \\
\text { dalam } \\
\text { pengembangan }\end{array}$ & $\begin{array}{l}\text { Mengikutsertakan } \\
\text { dalam berbagai } \\
\text { macam pelatihan } \\
\text { Meningkatkan } \\
\text { kualitas sarana } \\
\text { dan prasarana } \\
\text { penunjang } \\
\text { pariwisata }\end{array}$ \\
\hline
\end{tabular}

Vol.14 No.3 Oktober 2019

\section{Open Journal Systems}




\begin{tabular}{|c|c|c|}
\hline & $\begin{array}{l}\text { pariwisata Kota } \\
\text { Batu }\end{array}$ & \\
\hline Ancaman (T) & Strategi ST & Strategi WT \\
\hline $\begin{array}{l}\text { Tuntutan setiap } \\
\text { destinasi untuk } \\
\text { berstandar } \\
\text { internasional } \\
\text { Terbatasnya } \\
\text { jumlah SDM } \\
\text { Bencana alam }\end{array}$ & $\begin{array}{l}\text { Peningkatan } \\
\text { kemampuan } \\
\text { untuk } \\
\text { berkomitmen } \\
\text { dalam } \\
\text { pengembangan } \\
\text { pariwisata } \\
\text { Meningkatkan } \\
\text { kualitas SDM } \\
\text { dalam } \\
\text { menghadapi } \\
\text { pasar } \\
\text { persaingan } \\
\text { bebas } \\
\text { Peningkatan } \\
\text { mutu dan } \\
\text { kelengkapan } \\
\text { data terkait } \\
\text { jumlah } \\
\text { wisatawan }\end{array}$ & $\begin{array}{l}\text { Penambahan dana } \\
\text { operasional } \\
\text { (APBD) } \\
\text { Pendataan secara } \\
\text { lebih baik }\end{array}$ \\
\hline
\end{tabular}

Sumber: Hasil penelitian 2018

Berdasarkan analisis tersebut diatas maka dapat diidentifikasi beberapa factor keberhasilan dalam pencapaian tujuan dan misi Kota Batu yang berdaya saing diataranya adalah:

1. Pengembangan pasar wisatawan yaitu dengan melakukan promosi bertema spesifik yang sesuai dengan budaya daerah dan sebaiknya dikelola oleh lembaga promosi terkait (BPPD). Penggunaan media digital dalam mempromosikan pariwisata secara tepat sasaran. Pelaksanaan beberapa event di Kota Batu serta pemasangan penunjuk arah setiap objek wisata.

2. Pengembangan produk wisata yaitu dengan meningkatkan kualitas pelayanan produk/jasa pariwisata. Merancang atraksi tahunan sebagai kalender pariwisata dengan menampilkan atraksi daerah kota Batu. Serta mengembangkan event yang bersumber dari masyarakat baik event tradisional, modern ataupun tradisionel yang dikemas modern

3. Pengembangan SDM melalui peningkatan pengetahuan, pemahaman

Vol.14 No.3 Oktober 2019 dan kesadaran dari semua pihak terhadap permasalahan kepariwisataan.

Peningkatan kemampuan penguasaan bahasa asing bagi bagi pelaku usaha jasa pariwisata serta menguasaan informasi dan pelaporan perkembangan ODTW bagi kalangan pemandu wisata.

1. Pengembangan paket wisata khusus yaitu dengan penambahan event di Kota Batu misalnya Batu Travel Mart (BTM), Batu Flora Festival (BFF) Batu Night Criterium dll

2. Mengembangkan jejaring dan kemitraan pariwisata yang berkualitas dan berkesinambungan yaitu dengan pengelolaan biro perjalanan wisata baik skala local, nasional maupun internasional.

Peningkatan kualitas dan keragaman produk usaha dan jasa pariwisata melalui pengembangan profesionalisme sumber daya manusia yang terlibat dalam kegiatan pariwisata. Peningkatan kualitas Pendidikan, peningkatan frekuensi Pendidikan non formal secara berkesinambungan dalam bentuk kampanye sadar wisata dan bimbingan masal pada instansi terkait dan pengusaha kecil.

Upaya Dinas dalam mengembangkan pariwisata yang berdaya saing

\section{Program pengembangan destinasi}

Kota Batu selalu konsisten dalam meningkatkan kemampuan pengelolaan potensi yang dimiliki dan selalu menjaga kelestarian lingkungan. Berdasar strategi generic (generic strategies) Porter, Kota Batu menggunakan strategi diferensiasi untuk mencapai keunggulan kompetitif. Menurut Porter (1994) strategi untuk meningkatkan keunggulan kompetitif didasarkan atas tiga kriteria : harga, diferensiasi dan focus. Hal serupa juga disampaikan oleh Prasetya dkk (2007) bahwa untuk mencapai keunggulan bersaing maka harus didukung oleh strategi generic yang meliputi kepemimpinan biaya, diferensiasi dan focus. Strategi diferensiasi yaitu strategi dengan menonjolkan keunikan suatu produk yang secara umum dihargai oleh pembeli (Porter, 1994). Akan tetapi hal tersebut http://ejurnal.binawakya.or.id/index.php/MBI 
bertentangan dengan pendapat David (2006) yang menyatakan bahwa differensiasi tidak menjamin keunggulan kompetitif khususnya jika produk standar memenuhi kebutuhan konsumen atat imitasi cepat yang dilakukan oleh pesaing. Strategi ini akan berhasil dengan menetapkan harga yang lebih tinggi dari pesaing. Beberapa destinasi di Kota Batu memang memiliki kesamaan dengan destinasi yang ada di daerah lain. Wisatawan seharusnya dapat mengunjungi destinasi terdekat, akan tetapi dengan keunikan yang dimiliki Kota Batu menjadikan kota ini masih banyak dikunjungi oleh banyak wisatawan. Walaupun tarif yang dikenakan tidak murah, tidak menjadikan Kota Batu sepi pengunjung. Hal tersebut didukung oleh pendapat David (2006) bahwa keunggulan kompetitif adalah kemampuan destinasi untuk melakukan sesuatu yang tidak dapat dilakukan dengan baik atau bahkan tidak mampu dilakukan oleh pesaingnya. Kota Batu sangat diuntungkan dengan kondisi geografisnya. Sehingga dapat disimpulkan bahwa program pengembangan destinasi dapat dilakukan dengan : 1. pengembangan objek pariwisata unggulan; 2. Peningkatan pembangunan sarana dan prasarana; 3. Pengembangan paket wisata unggulan; 4. Pengembangan daerah tujuan wisata; 5 . Pemantauan dan evaluasi pelaksanaan program pemasaran.

\section{Program pemasaran pariwisata}

Program pemasaran bertujuan untuk menciptakan pariwisata yangmemiliki daya jual yang tinggi. Cairiwati (2012) menjelaskan bahwa salah satu cara komunikasi pemasaran yang dilakukan adalah dengan branding. Penggunaan Shining Batu menjadikan Kota Batu semakin dikenal.

\section{Program pengembangan kemitraan}

Program ini bertujuan untuk meningkatkan kualitas SDM aparatur dan masyarakat yaitu dengan kegiatan yang meliputi kegiatan Pendidikan dan pelatihan formal serta kerjasama dengan lembaga lain terkait dengan pengembangan informasi data base.

\section{PENUTUP}

\section{Kesimpulan}

Berdasarkan analisis SWOT yang telah dilakukan menunjukkan hasil bahwa pengembangan pariwisata Kota Batu telah dilakukan dan diterapkan oleh pemerintah daerah beserta masyarakat sekitar. Banyak potensi wisata yang dapat dikembangkan menjadi ODTW yang banyak diminati dan dikunjungi wisatawan. Akan tetapi permasalahan yang dihadapi saai ini adalah kualitas dan kuantitas SDM yang memiliki keahlian di bidang pariwisata sangatlah sedikit.

\section{Saran}

Diperlukan upaya pelatihan dan pemahaman terkait pariwisata mengingat tunutan MEA saat ini adalah mewujudkan industry pariwisata yang berdaya saing tidak hanya local, nasional akan tetapi regional dan intenasional.

\section{DAFTAR PUSTAKA}

[1] AL-MASROORI, R. S. 2006b. Destination Competitiveness: Interrelationships between destination planning and development strategies and stakeholders' support in enhancing Oman's tourism industry. Unpublished doctoral dissertation). Griffith University, Australia.

[2] Anasthacia, Novrani. 2007. Analisis Permintaan Wisatawan Nusantara Objek Taman Nasional Karimunjawa Kabupaten Jepara. Skripsi. Tidak dipublikasikan. Semarang: Universitas Diponegoro.

[3] Badan Pusat Statistik 2012. Indonesia Tourism Prospect. Jakarta,Indonesia.

[4] Badan Pusat Statistik. 2013a. The development of tourism and national transportations in Indonesia [Online]. Jakarta, Indonesia: BPS.

[5] CHEN, C. M., CHEN, S. H. \& LEE, H. T. 2011b. The destination competitiveness of Kinmen's tourism industry: exploring the interrelationships between tourist perceptions, service performance, customer satisfaction and sustainable tourism. Journal of Sustainable Tourism, 19, 247-264. 
[6] CHI, C. G. Q. \& QU, H. 2008. Examining the structural relationships of destination image, tourist satisfaction and destination loyalty: An integrated approach. Tourism Management, 29, 624-636.

[7] CRACOLICI, M. F., NIJKAMP, P. \& RIETVELD, P. 2008. Assessment of tourism competitiveness by analysing destination efficiency. Tourism Economics, 14, 325-342.

[8] CROUCH, G. I. \& RITCHIE, J. R. B. 1999. Tourism, Competitiveness and Societal prosperity. Journal of Business Research, 44, 137-152.

[9] DAVID,R,FRED.2006 Manajemen Strategis. Jakarta. Salemba Empat.

[10]DWYER, L. \& KIM, C. 2003. Destination competitiveness: determinants and indicators. Current issues in tourism, 6, 369414.

[11]GOMEZELJ, D. O. \& MIHALIC, T. 2008. Destination competitiveness--Applying different models, the case of Slovenia. Tourism Management, 29, 294-307.

[12] KOZAK, M., BALOGLU, S. \& BAHAR, O. 2010b. Measuring Destination Competitiveness: Multiple Destinations Versus Multiple Nationalities. Journal of Hospitality Marketing \& Management, 19, 56-71.

[13]Ross, Glenn F, 1998. Psikologi Pariwisata. Diterjemahkan oleh Marianto Samosir. Jakarta: Yayasan Obor Indonesia.

[14]Sutrisno, Tanio. 2014. "Perilaku Konsumen". Melalui: https://taniosutrisno.wordpress.com /2014/09/25/perilaku-konsumen-teori-ciriciri-dan-manfaat-perilaku-konsumen/ [16/09/15]

[15]TIMOTHY , D. J. 2011. Cultural Heritage and Tourism: An Introduction, Toronto, Channel View Publications.

[16]UNWTO. 2008. Tourist 2020 vision [Online]. http://www.unwto.org/facts/eng/vision/htm.

[17] YOON, Y. \& UYSAL, M. 2005b. An examination of the effects of motivation and satisfaction on destination loyalty: a

Vol.14 No.3 Oktober 2019 structural model. Tourism Management, 26, 45-56.

[18] YUKSEL, A. 2007. Tourist shopping habitat: Effects on emotions, shopping value and behaviours. Tourism Management, 28, 58-69. 